\title{
Ruth Hubbard Cousins: saluting her centenary
}

\section{Harold Takooshian' ${ }^{1}$, Florence L. Denmark², Carol Tracy ${ }^{3}$, Joan Cousins ${ }^{4}$}

\author{
${ }^{1}$ Fordham University \\ $113 \mathrm{~W} .60^{\text {th }}$ Street, New York, NY, 10023, United States of America \\ ${ }^{2}$ Pace University \\ 1 Pace Plaza, New York, NY 10038, United States of America \\ ${ }^{3}$ Naples, FL, United State of America \\ ${ }^{4}$ Medford MA, United State of America
}

\begin{abstract}
May 21, 2020, marks 100 years since the birth of the legendary Ruth Hubbard Cousins (1920-2007). This salute is in two parts: (1) it recounts the extraordinary career of Ruth Cousins, and how her 33 years of leadership of Psi Chi has now touched the lives of over 750,000 Psi Chi life members at over 1,150 campuses world-wide; (2) Ruth's two daughters Carol and Joan recount how they helped their recently-widowed mother since 1959 to expand Psi Chi. Psychology world-wide is not the same because of the remarkable legacy of Ruth Cousins.
\end{abstract}

Key words: Psi Chi, Psi Beta, Ruth Cousins, psychology students

May 21, 2020 marks 100 years since the birth of Ruth Hubbard Cousins the legendary Executive Director for 33 years (1958-1991) of Psi Chi - what is now the International Honor Society for Psychology. This centenary is an apt time for those unfamiliar with Ruth to learn about this extraordinary life, which has touched tens of thousands of others' lives world-wide.

Those who knew Ruth would agree with esteemed historian-psychologist Michael Wertheimer: "This centenary of Ruth's birth is an occasion that deserves immense celebration. Ruth WAS Psi Chi. Her dedication, contributions, endless concerns, smiles, encouragement, selfless devotion, vision and inspiration are what changed a modest little endeavor to an enormous world-wide society for the recognition of academic excellence. Few people have such huge beneficial effect on the lives of so many thousands of people. So many of us are deeply indebted to her."

At Yale University in 2004, historian Daniel P. Bockert described Psi Chi as "the house that Ruth built" (Greer, 2004) - a house that now numbers over 750,000 life member student, faculty, and alumni at over 1,150 campuses across ten nations (Novikova et al., 2019). 


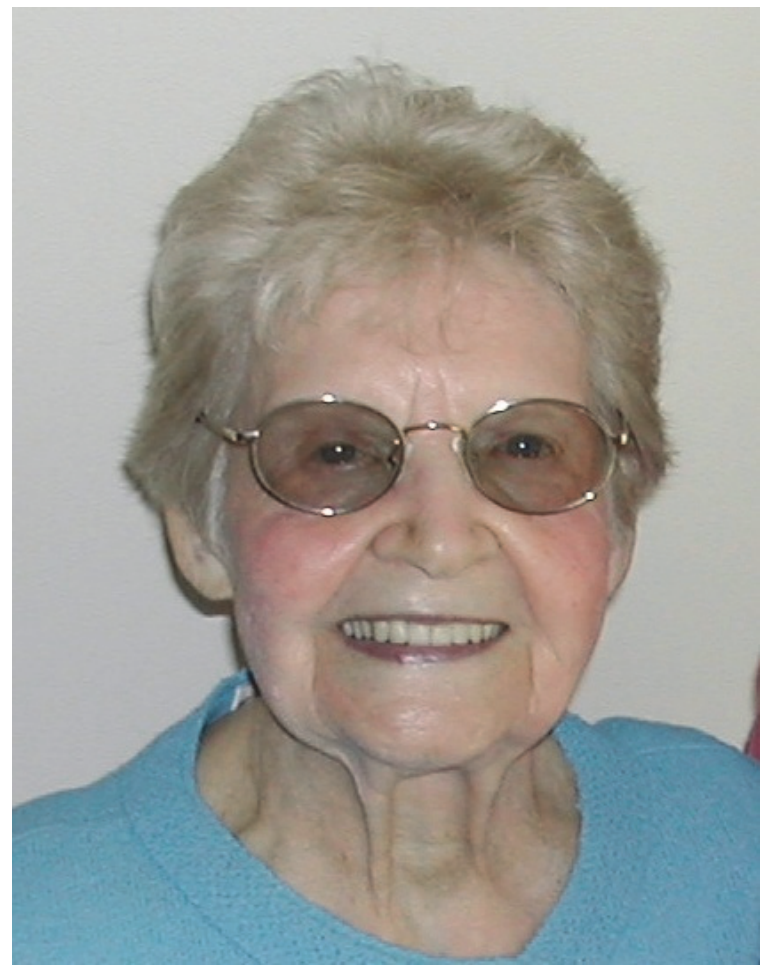

Figure 1. Ruth Hubbard Cousins, 1920-2007

(photo from the personal archive of the Cousins family)

One aim of the RUDN Journal is to salute outstanding psychologists and educators in Russia and world-wide. This salute is in two parts: (1) a brief biography of Ruth Cousins, and (2) a personal remembrance shared by her two beloved daughters Carol and Joan.

\section{A brief biography of Ruth Cousins}

(by Harold Takooshian \& Florence L. Denmark)

Ruth Hubbard was born in Waleska, Georgia on May 21, 1920, one of six children born to two teachers - Charles and Frances Boston Hubbard. After high school, Ruth moved to New York City, and met and married James Franklin Cousins at Grace Methodist Church in 1942. Their first daughter Carol was born just before World War II drew her father into the U.S. Navy to fight overseas for three years. The year after he returned, their second daughter Joan was born. The Cousins moved to Virginia in 1953, where Jim worked as a certified public accountant, and Ruth enrolled in George Washington University for her BA and MA in child psychology.

In 1958, GWU Professor Eva Johnson asked her gifted student Ruth to fill the vacancy of Executive Secretary-Treasurer of Psi Chi, the National Honor Society in Psychology, for a modest salary of $\$ 3,000$ per year. Ruth already had a full plate with her family and education but, with Jim's encouragement, she agreed to help for just one year, then resign.

But fate intervened. One year later, Ruth rushed Jim to the hospital with a ruptured appendix. Jim died unexpectedly on September 14, 1959. Ruth suddenly found herself a single mother raising two children, with no income. With great courage, Ruth decided to enlist her daughters to help their mom to expand Psi Chi. 
The rest is history. In 1958, when Ruth began, Psi Chi was little more than a large closet in the attic of the APA building in Washington D.C., which stored membership cards. But Ruth combined her brilliant vision for the society with her own grace and talents. When she left in 1991, Psi Chi was by most measures the world's largest honor society in any field, with a dynamic program of conferences, publications, awards, activities, and 221,573 life members at 734 U.S. campuses. During those 33 years, Psi Chi registered as an honor society with the Association of Collegiate Honor Societies (ACHS), an affiliate of the APA and Association for Psychological Science (APS), and the founder of Psi Beta - the Psychology Honor Society for two-year colleges. In 2001, Ruth received the APA Presidential Citation, recognizing that her work with Psi Chi touched the lives of untold thousands of students and professors, many of whom were unaware of her work.

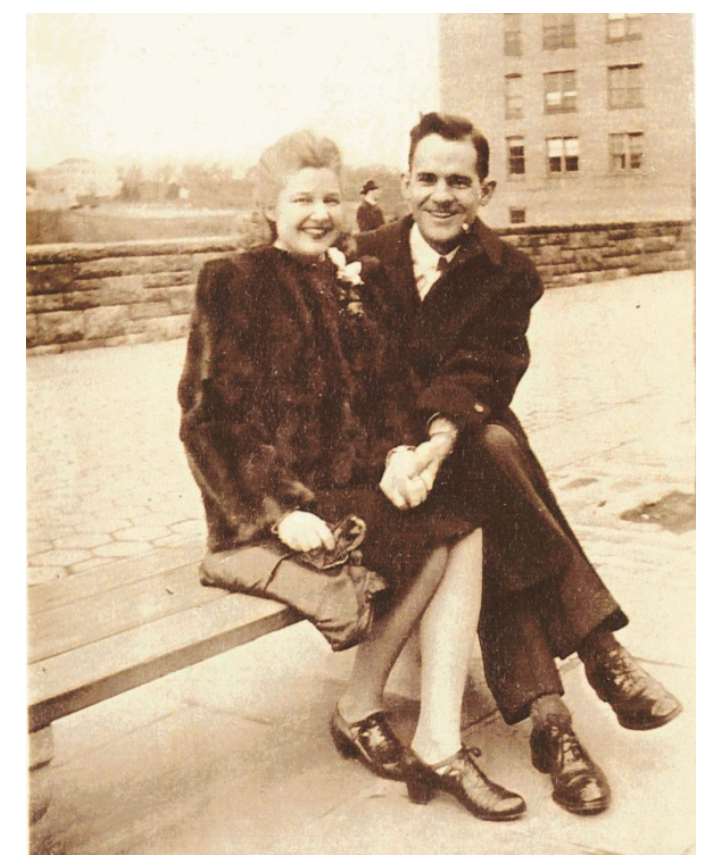

Figure 2. Ruth Hubbard \& Jim Cousins, just engaged, NYC, 1940 (photo from the personal archive of the Cousins family)

Even those who met Ruth briefly were quickly impressed by her gracious charm, brilliant mind, and gift to bring out the best in others. Among her many leadership roles, Ruth was a member of the National Press Club in Washington D.C., and one of the first women to serve on the board of the American Society of Association Executives (AESA).

Ruth was married to Jim for 18 years, and for 48 years was a single widow. Ruth tells two stories about her beloved Jim. (1) In 1959, in his hospital bed, Jim asked Ruth to remarry if he "did not make it," so she "would not deprive another man of the joy" that she brought to him. (2) While many men were naturally attracted to Ruth's sparkle, she explained to them that Jim was a proud Navy veteran buried in Arlington National Cemetery, so she could never re-marry if she wanted to be buried beside her Jim. Today Ruth and Jim lie side by side for eternity, after two lives well-lived. 


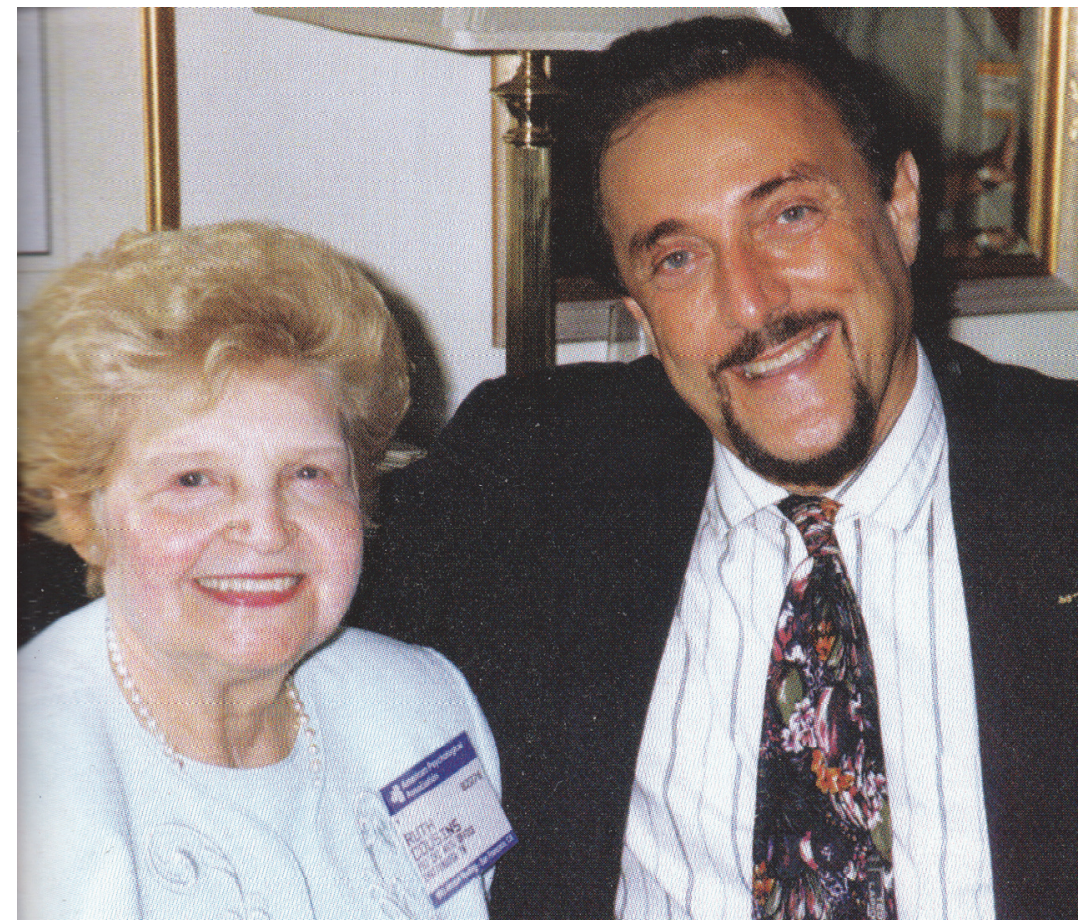

Figure 3. Ruth Cousins and Philipp Zimbardo at APA meeting, San Francisco, 1991 ( $p$ hoto from the personal archive of the Cousins family)

More detailed accounts of Ruth's life appear online - with Wikipedia (https://en.wikipedia.org/wiki/Ruth_Hubbard_Cousins), APA (Hogan, 2009), Psi Chi (Mathie, 2007; Wilson, 1991), the press (Schudel, 2007), and RUDN Journal of Psychology and Pedagogics (Takooshian, 2019).

\section{Remembering our mother: Ruth Hubbard Cousins}

(by Carol Cousins Tracy \& Joan Hubbard Cousins)

Back in 1958, our dear mother, Ruth Hubbard Cousins, was asked to fill in as Psi Chi's Executive Secretary for one year. She had two daughters - Carol, 15, and Joan, 11 - plus she was working on her master's degree in psychology at George Washington University. Despite these challenges, Ruth agreed to take the part-time position in late 1958. She soon discovered that Psi Chi's income had never exceeded its expenses during its 29-year history. James Franklin Cousins, our father, was a CPA who immediately offered help. He redesigned the bookkeeping system, created a balanced budget, and made sure all required federal filings were done.

Psi Chi's office was in a small attic room on the $5^{\text {th }}$ floor of the American Psychological Association's (APA's) first headquarters building. While our father worked on Psi Chi's financial needs, our mother updated the newsletter and organized the office files. Carol and Joan pitched in by typing, filing membership cards, preparing mailings, sweeping and dusting. Less than a year later, Ruth attended her first national Psi Chi meeting, held during the APA convention on Labor Day Weekend. Our father fell ill over that weekend. On her return, Ruth quickly got him admitted to a hospital. He died a week later. Seven months later, 
Ruth lost her mother. That's when Ruth's resilience and tenacity emerged from beneath her southern charm. That's when her one-year commitment started growing to 33 years - becoming her life's work.

As a widow and single mother, Ruth certainly needed a job. But what really motivated her was a lifelong love for learning and a natural talent for mentoring young people. In 1958, Psi Chi members received only one benefit: a certificate acknowledging their achievement. Over the next decades, Ruth envisioned and collaborated with others to create many more benefits for Psi Chi's student members: opportunities to receive career coaching, hone research skills, win research grants and awards, gain professional experience, and interact with psychology's most distinguished thought leaders. Ruth transformed Psi Chi from an honorary society to an honor society, one whose membership is based on merit.

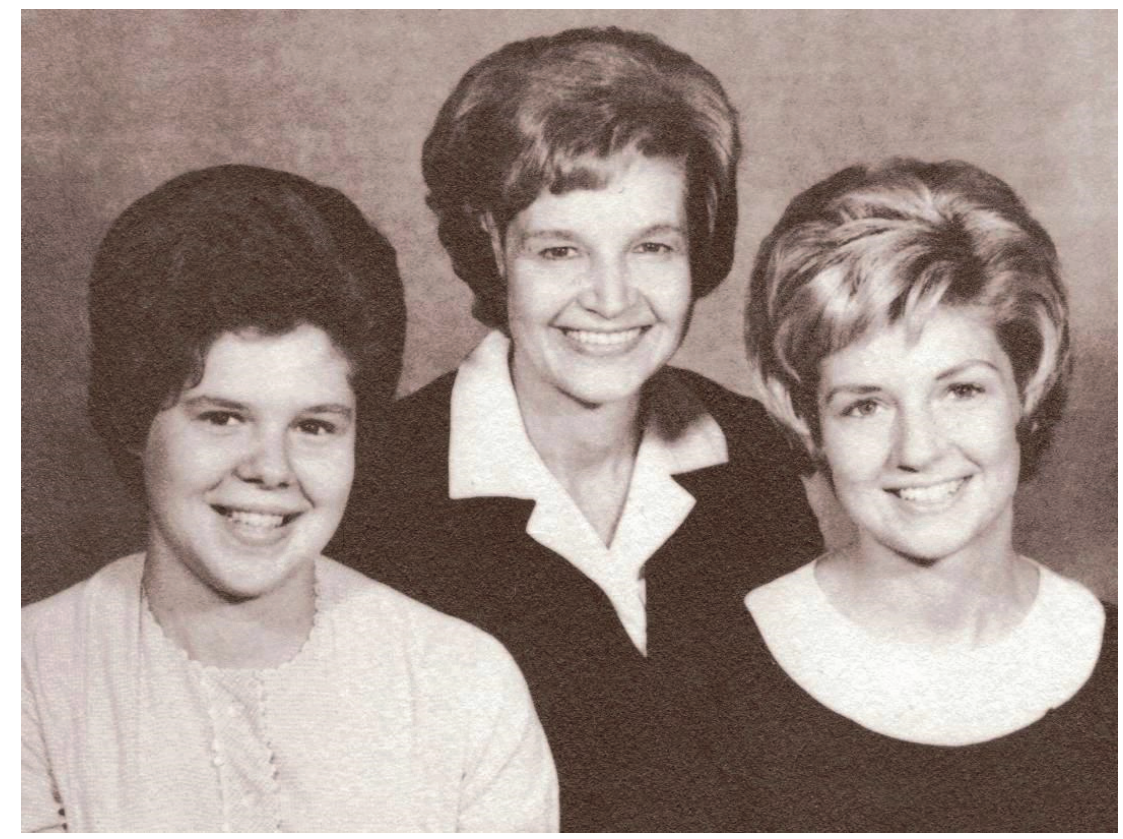

Figure 4. Joan, Ruth \& Carol Cousins, Washington, D.C., 1961 (photo from the personal archive of the Cousins family)

In 1981, Ruth worked with her daughter Carol Tracy to found Psi Beta, an honor society designed to meet the needs of high-achieving psychology students attending two-year colleges. Our mother would be very proud of Psi Chi as it continues to identify unmet needs of international psychology students and develops innovative programs to meet them. She also would be delighted that Psi Chi has continued to flourish. Using the systems and coaching her husband provided, Ruth made sure Psi Chi increased its financial cushion every year.

Edwin B. Newman, the co-founder of Psi Chi, wrote in a 1989 letter to our mother: "Far more than most people realize, Psi Chi is not what we founded, it is what you have made it."

Since we were by our mother's side when she began working at Psi Chi, we witnessed that transformation. Dr. Newman, we wholeheartedly agree. What an honor to be her daughters! 


\section{References}

Greer, M. (2004, November). Psi Chi turns 75, celebrates its beginnings. APA Monitor on Psychology, 35 (10), 11. Retrieved from www.apa.org/monitor/nov04/psichi

Hogan, J.D. (2009). Ruth Hubbard Cousins, 1920-2007. American Psychologist, 64(1), 48. https://doi.org/10.1037/a0013672

Mathie, V.A. (2007, Spring). Tribute to Ruth Hubbard Cousins. Eye on Psi Chi, 11 (3), 8-9. Retrieved from https://cdn.ymaws.com/www.psichi.org/resource/resmgr/about_images/ruth_hubbard_ cousins.pdf

Novikova, I.A., Tarkhova, V.S., Kardashova, S.Z., \& Kharitonenko, A.A. (2019). First and Only Russian Psi Chi Chapter: Five years at the RUDN University! RUDN Journal of Psychology and Pedagogics, 16(1), 101-109. http://dx.doi.org/10.22363/2313-16832019-16-1

Schudel, M. (2007, January 28). Ruth Hubbard Cousins: Led psychology honor society. The Washington Post. Retrieved from www.washingtonpost.com/wpdyn/content/article/2007/01/27/AR2007012701316.html

Takooshian, H. (2019). Psi Chi at 90 years. RUDN Journal of Psychology and Pedagogy, 16(2), 224-235. http://dx.doi.org/10.22363/2313-1683-2019-16-2-224-236

Wilson, K. (1991). A tribute to Ruth Cousins from the incoming Psi Chi Executive Officer. Psi Chi Newsletter, 17(5), 4-17.

Article history:

Received: 15 May 2020

Revised: 25 May 2020

Accepted: 28 May 2020

\section{For citation:}

Takooshian, H., Denmark, F.L., Tracy, C., \& Cousins, J. (2020). Ruth Hubbard Cousins: Saluting her centenary. RUDN Journal of Psychology and Pedagogics, 17(2), 357-364. http://dx.doi.org/10.22363/2313-1683-2020-17-2-357-364

\section{Bio notes:}

Harold Takooshian, $\mathrm{PhD}$, is Professor of Psychology, Urban Studies, and Organizational Leadership at Fordham University (USA, New York). He is Past-President of the APA Division of International Psychology (2003), past officer and President of Psi Chi from 1993-2000, a Distinguished Member of Psi Chi and Psi Beta, and one of thousands of people whose life was deeply touched by the Cousins family. E-mail: takoosh@aol.com

Florence L. Denmark, PhD, is the Robert Scott Pace Professor Emerita of Psychology at Pace University (New York, USA). She is Past-President of the American Psychological Association and its Division of International Psychology, and a Past-President and Distinguished member of Psi Chi, who worked closely with her dear friend Ruth Cousins. E-mail: fdenmark@pace.edu.

Carol Tracy went on to earn her BA in Education from Duke University. She taught kindergarten, first grade, then high school mathematics. Carol was the Psi Chi Financial Officer for 7 years. From 1981 to 2005, Carol served as the founding Executive Director of Psi Beta - the Psychology Honor Society for two-year colleges. Carol and her spouse Ferb are retired in Naples, FL. They have three children, nine grandchildren and four greatgrandchildren. E-mail: carol.tracy1@gmail.com 
Joan Cousins went on to her BS in Journalism and MS in Communications Research at Boston University, MFA in Writing (Creative Nonfiction) at Vermont College of Fine Arts, and professional training and certifications in counseling, accounting, and taxation. For over 20 years, Joan has been an accountant and business coach, plus eight years with the Kripalu Center. Since 2015, Joan and her spouse Alice have been exploring Alaska and the wilder parts of North America, as Joan writes her memoir. E-mail: CousinsAdventureNow@gmail.com

\title{
DOI 10.22363/2313-1683-2020-17-2-357-364 Биографическая статья
}

\section{К столетию легендарной Рут Хаббард Казинс}

\author{
Г. Такушьян ${ }^{1}$, Ф.Л. Денмарк ${ }^{2}$, К. Трейси ${ }^{3}$, Дж. Казинс ${ }^{4}$ \\ ${ }^{1}$ Университет Фордхэм \\ Соединенные Штаты Америки, 10023, Нью-Йорк, 60-я ул., 113 \\ ${ }^{2}$ Университет Пейс \\ Соединенные Штаты Америки, 10038, Нью-Йорк, Пейс плаза, 1 \\ ${ }^{3}$ Неаполь, Флорида, Соединенные Штаты Америки \\ ${ }^{4}$ Медфорд, Массачусетс, Соединенные Штаты Америки
}

\begin{abstract}
Аннотация. 21 мая 2020 года исполнилось 100 лет со дня рождения легендарной Рут Хаббард Казинс (1920-2007). Этому юбилею посвящена данная статья, состоящая из двух частей. В первой части рассказывается о необычайной карьере Рут Казинс и о том, как еe 33-летнее руководство Psi Chi (Психологического общества почета) коснулось жизни более 750000 членов Psi Chi в более чем 1150 кампусах по всему миру. Во второй части две дочери Рут - Кэрол и Джоан - рассказывают о том, как с 1959 года они помогали своей недавно овдовевшей матери развивать Psi Chi. Психология во всем мире изменилась к лучшему благодаря замечательному наследию Рут Казинс.
\end{abstract}

Ключевые слова: Psi Chi, Psi Beta, Рут Казинс, студенты-психологи

\section{История статьи:}

Поступила в редакцию: 15 мая 2020 г.

Принята к печати: 28 мая 2020 г.

\section{Для цитирования:}

Takooshian H., Denmark F.L., Tracy C., Cousins J. Ruth Hubbard Cousins: saluting her centenary // Вестник Российского университета дружбы народов. Серия: Психология и педагогика. 2020. Т. 17. № 2. С. 357-364. http://dx.doi.org/10.22363/2313-16832020-17-2-357-364

\section{Сведения об авторах:}

Гарольд Такушьян, Ph.D., профессор психологии, урбанистики и организационного лидерства в Университете Фордхэм (США, Нью-Йорк). Был президентом отделения международной психологии Американской психологической ассоциации (2003 г.), а также офицером и президентом Psi Chi (1993-2000 гг.). Является заслуженным членом Psi Beta и Psi Chi, а также одним из тысяч людей, чья жизнь во многом изменилась благодаря встречи с семьей Казинс. E-mail: takoosh@aol.com 
Флоренсе Л. Денмарк, Ph.D., почетный профессор Университета Пэйс (США, НьюЙорк). Была президентом Американской психологической ассоциации (1980г.), 52-го отделения международной психологии Американской психологической ассоциации, а также президентом Psi Chi. Является заслуженным членом Psi Chi. B свое время работала в Psi Chi вместе с Рут Казинс, которая была ее подругой. E-mail: fdenmark@pace.edu.

Кэрол Трэйси, старшая дочь Рут Казинс, получила степень бакалавра в области образования в Университете Дьюка. Работала в детском саду, преподавала в начальной, а затем в средней математической школе по математике. Кэрол была финансовым директором Psi Chi в течение 7 лет. В 1981-2005 гг. занимала должность исполнительного директора Psi Beta - Психологического общества почета для двухлетних колледжей. Сейчас Кэрол и ее супруг Ферб на пенсии в Неаполе, штат Флорида. У них трое детей, девять внуков и четверо правнуков. E-mail: carol.tracy1@ gmail.com

Джсоан Казинс, младшая дочь Рут Казинс, получила степени бакалавра в области журналистики и магистра наук в области коммуникационных исследований в Бостонском университете, степень магистра творческого письма (Creative Nonfiction) в колледже изящных искусств Вермонта, а также профессиональную подготовку и сертификацию в области консультирования, бухгалтерского учета и налогообложения. Уже более 20 лет Джоан работает бухгалтером и бизнес-тренером, восемь из них - в Центре Крипалу. E-mail: CousinsAdventureNow@gmail.com 